\title{
Determination of In vitro antimicrobial activity of homeopathy medicines
}

\author{
Soyoda Mokarroma and Tahmina Shammi* \\ Department of Microbiology, Stamford University Bangladesh, 51, Siddeswari Road, Dhaka 1217, Bangladesh
}

Received 12 February 2018/Accepted 24 March 2018

\begin{abstract}
Homeopathy is a popular alternative medicine. The mechanism of action of homeopathic drug has not been clarified but it has been found to be effective against various diseases including diarrhea, dysentery, otitis media, eczema and even cancer. After qualifying thorough investigation, it can be used against antibiotic tolerance and multi drug resistant bacteria. In a recent study, bactericidal effect of homeopathic remedies has been investigated. But such an effect is not in accordance with the general principles of homeopathy. To test this paradigm, in vitro antimicrobial effects of four homeopathic drugs Aconite 30, Arsenicum album 30, Mercuric corrosivus 30 and Mercury solution 200 against five common intestinal pathogens, including- Escherichia coli, Klebsiella sp., Salmonella sp. Pseudomonas sp., and Bacillus sp have been observed. Standard agar well diffusion technique and macrodilution technique were followed. But, tested homeopathic drugs did not show any significant effect on any of the five pathogens. Rigorous study against other organism is required to fully understand antimicrobial activity and other mechanism of action.
\end{abstract}

Key words: Homeopathy; Antibiotic; Multidrug resistant bacteria; MIC

Homeopathy is a therapeutic method, first developed by Samuel Hahnemann (1755-1843) and is now practiced throughout the world. This method use preparations of substances whose effects when administered to healthy subjects correspond to the manifestations of the disease (symptoms, clinical signs, pathological states). Homeopathy has two main principals $(1,2)$. Firstly, 'like cures like' principle, patients with particular signs and symptoms can be helped by a homeopathic remedy that produces these signs and symptoms in healthy individuals. Secondly, homeopathic remedies can retain its biological activity after repeated dilution and succession even when diluted beyond Avogadro's number (3).

Though lacking much scientific evidence, it is considered as alternative medicine due to its low cost, fewer side effects and occasional failure of other treatment methodology (4). Shortage of new antibiotics and development of drug resistant organism is a matter of concern for public health worldwide and often lead to the quest of alternative medicine to microbial diseases. Many homeopathy drugs are now in use against common bacterial diseases. Although, mechanism of action of these medicines is not yet identified, they are claimed to be potent antibiotic or similibiotic (5).

In present study, four homeopathy drugs Aconite 30, Arsenicum album 30, Mercuric corrosivus 30 and Mercury solution 200 (6), which are commonly used

*Corresponding Author: Mailing address. Tahmina Shammi, Senior Lecturer, Department of Microbiology, Stamford University Bangladesh, 51 Siddeswari Road, Dhaka 1217, Bangladesh, Bangladesh; E-mail: tahminashammi@yahoo.com. against diarrhea and dysentery, were tested for their antimicrobial activity against five common intestinal pathogens, including- Escherichia coli, Klebsiella sp., Salmonella sp. Pseudomonas sp., and Bacillus sp. Result of this study can provide an evidence to either antimicrobial property or placebo effect of these drugs.

\section{MATERIALS AND METHODS}

Sample collections \& sample processing. Sample drugs were randomly collected from homeopathic drug stores at different areas of Dhaka city during March, 2018. Standard technique, suggested by American Public Health Association (APHA, 1998) was followed. During collection drug satisfied the manufacturing \& expiry dates \& storage criteria.

Determination of antimicrobial activity

Agar well diffusion technique. To observe in vitro antimicrobial activity, a standard procedure of agar well diffusion method was performed $(7,8)$. Agar well diffusion assay was observed against five common gastrointestinal pathogens including, Escherichia coli. Pseudomonous sp., Klebsiella sp., Bacillus sp., and Salmonella sp. Broth cultures of these organisms in Muller-Hinton Broth (MHB) were adjusted to the turbidity of Macfarland standard of 0.5 at first. Then with sterilized cotton swab, bacterial suspension was evenly spread on Muller-Hinton agar for confluent growth of each organism. With sterile cork-borer, wells were made on agar plates and $100 \mu \mathrm{l}$ of each sample was added. For positive and negative control, disk of gentamicin $10 \mu \mathrm{g}$ and Sterile MHB were used respectively. After overnight incubation at $37{ }^{\circ} \mathrm{C}$, presence of clear zone was observed and measured for antimicrobial activity (9).

Determination of minimum inhibitory concentration by macrodilution technique. For determination of minimum inhibitory concentration, macrodilution or tube dilution method was followed. Again broth cultures of five tested organisms were adjusted to the turbidity of $0.5 \mathrm{McFarland}$ solutions. For MIC of each drug, 7 vials containing $3 \mathrm{ml}$ Muller Hilton broth were taken. 7 different volumes- $16 \mu \mathrm{l}, 32 \mu \mathrm{l}, 64 \mu \mathrm{l}, 128 \mu \mathrm{l}, 256 \mu \mathrm{l}, 512 \mu \mathrm{l}$ and $1024 \mu \mathrm{l}$ of drug was added after withdrawing same amount of media. And finally $100 \mu \mathrm{l}$ of bacterial suspension was added. After overnight incubation at $37^{\circ} \mathrm{C}$, vials were observed against light to identify the MIC.

\section{RESULTS AND DISCUSSIONS}

All four drugs showed small zone or no zone of inhibition against five tested organisms. Mercury 
solution $(\mathrm{Q}=200)$ produced zone of inhibition against three of the pathogens. A $5 \mathrm{~mm}$ in diameter against $E$. coli, $4 \mathrm{~mm}$ against Salmonella sp. and Bacillus sp. and no inhibition against Klebsiella sp. and Pseudomonas sp. Mercuris corrosivus showed inhibition zone of 2 $\mathrm{mm}$ in diameter against three of the pathogens whereas Aconite and Arsenicum album against two and one pathogens respectively. Zone of inhibition exerted by Aconite against Klebsiella sp. was $6 \mathrm{~mm}$ in diameter, which was maximum in this study. No zone of inhibition was found against Pseudomonas sp. by any of the medicine. Result of agar well diffusion is shown in Table 1.

All four drugs were found to have minimum inhibitory concentrations (MIC) between $256 \mu 1 / 3 \mathrm{ml}$ to $1024 \mu \mathrm{l} / 3 \mathrm{ml}$ for five of the pathogens. Result of (MIC) is shown in Table 2.

\section{DISCUSSION}

Diarrhoea and dysentery are two forms of gastroenteritis often caused by consumption of food contaminated with various pathogens (10). Along with oral rehydration therapy, various antibiotics are prescribed to shorten the duration of these diseases. But repetitive antibiotic treatment can increases the risk of antibiotic tolerance and selecting multi drug resistant bacteria. Again antibiotic can cause various side effects in patients. In the present study, four different homeopathic drugs were tested against five different pathogens. The four tested drugs showed to have insignificant bacterial inhibition in agar well diffusion method but showed variable efficiency in inhibiting bacteria by macrodilution process.

The principle of homeopathic drug is, it can retain its medicinal property even in extremely high dilutions $(1,3)$. But in the present study, the result was not directly relatable with this principle. Cause most of the drugs were found to be inhibitory at high concentrations, between 256 $\mu \mathrm{l} / 3 \mathrm{ml}$ to $1024 \mu \mathrm{l} / 3 \mathrm{ml}$.

Though, in some studies treatment with homeopathic drugs found to be effective against bacterial diseases (3, 11-14) and there are few report that homeopathic drugs found to be effective against bacterial diseases (3, 11-14) and there are few report that homeopathic drugs can work as similibiotics, that is they can induce immune system of the host as like a bacteria and therefore can cure patients (6). But, by so far, most of these studies do not have strong scientific background $(15,16)$ and extensive scientific research should be done to understand mechanism of action as well as antimicrobial activity of homeopathy medicines.

\section{CONCLUSION}

Homeopathy drugs have long been used as alternative

TABLE 1. Zone of inhibition by agar well diffusion (diameter in $\mathrm{mm}$ ) against different homeopathic drugs

\begin{tabular}{ccccccc}
\hline $\begin{array}{c}\text { Selected } \\
\begin{array}{c}\text { Homeopathic Drugs } \\
(\mathbf{n}=\mathbf{4})\end{array}\end{array}$ & Potency $\left(\boldsymbol{Q} / \mathbf{M T}^{5}\right)$ & $\begin{array}{c}\text { Salmonella } \\
\text { sp. }(\mathbf{m m})\end{array}$ & $\begin{array}{c}\text { Klebsiella } \\
\text { sp. }(\mathbf{m m})\end{array}$ & $\begin{array}{c}\text { E. coli } \\
(\mathbf{m m})\end{array}$ & $\begin{array}{c}\text { Pseudomonas } \\
\text { sp. }(\mathbf{m m})\end{array}$ & $\begin{array}{c}\text { Bacillus sp. } \\
(\mathbf{m m})\end{array}$ \\
\hline Aconite $^{1}$ & 30 & 0 & 6 & 3 & 0 & 0 \\
Arsenicum album $^{2}$ & 30 & 0 & 2 & 0 & 0 & 0 \\
Merc. cor. $^{3}$ & 30 & 2 & 0 & 2 & 0 & 2 \\
Merc. sol. $^{4}$ & 200 & 4 & 0 & 5 & 0 & 4 \\
\hline
\end{tabular}

\footnotetext{
${ }^{1}$ Symptoms: Stools small, frequent, bloody or slimy; fever, restlessness, anxiety, fear of death.

${ }^{2}$ Symptoms: Stools dark, putrid, mixed with blood ; during stool tenesmus and burning in rectum, great anguish, restlessness, fear of death; extreme thirst, aggravated at night, or after eating or drinking.

${ }^{3}$ Mercuris corrosives. Symptoms: Stools pure blood or bloody mucus. During stool straining and tenesmus. Severe pains in rectum after the discharge. Almost constant cutting pain in the abdomen.

${ }^{4}$ Mercury solution. Symptoms: Similar to Merc. cor. Symptoms are worse at night, and where there are profuse night sweats, especially on the head.

${ }^{5}$ Mother Tincture.
}

TABLE 2. Minimum Inhibitory Concentration (MIC) $(\mu 1 / 3 \mathrm{ml})$ of different homeopathic drugs

\begin{tabular}{ccccccc}
\hline $\begin{array}{c}\text { Selected } \\
\text { Homeopathic Drugs } \\
(\mathbf{n}=4)\end{array}$ & Potency $(\boldsymbol{Q} / \mathbf{M T})$ & $\begin{array}{c}\text { Salmonella } \\
\text { sp. }(\boldsymbol{\mu l})\end{array}$ & $\begin{array}{c}\text { Klebsiella } \\
\text { sp. }(\boldsymbol{\mu l})\end{array}$ & $\begin{array}{c}\text { E. coli } \\
(\boldsymbol{\mu l})\end{array}$ & $\begin{array}{c}\text { Pseudomonas } \\
\text { sp. }(\boldsymbol{\mu l})\end{array}$ & $\begin{array}{c}\text { Bacillus sp. } \\
(\boldsymbol{\mu l})\end{array}$ \\
\hline Aconite & 30 & 512 & 1024 & 1024 & Nil & 256 \\
Arsenicum album & 30 & 256 & 512 & 1024 & 256 & 512 \\
Merc. cor. & 30 & 256 & 512 & 256 & 256 & 512 \\
Merc. sol. & 200 & 1024 & 512 & 1024 & 256 & 256 \\
\hline
\end{tabular}


medicine. But their antimicrobial activity has not been clearly identified yet. In present study, no significant antimicrobial activity has been observed against five common intestinal pathogens. Antimicrobial activity against other pathogens can be observed in future endeavor.

\section{ACKNOWLEDGEMENT}

Special thanks to Microbiology Laboratory, Stamford University Bangladesh for laboratory facilities, technical assistance and financial aid.

\section{REFERENCES}

1. Swayne J. 2000. International Dictionary of Homeopathy. Churchill Livingstone, Edinburgh.

2. Hahnemann S. 1833. The homeopathic medical doctrine, or "Organon of the healing art". Dublin.

3. Ernst E. 2002. A systematic review of systematic reviews of homeopathy. British J. Clin. Pharm. 54 (6): 577-82.

4. Baran GR, Kiana MF, Samuel SP. 2014. Healthcare and Biomedical Technology in the 21st Century. Springer.

5. Mansoor A. 2012. Acute gastroenteritis- a homeopathic perspective. Available at: https://www.homeobook.com. Accessed April 9, 2018

6. Nambison KMN. 2009. Antibacterial activity of homoeopathic drugs in vitro (similibiotics). Available at: https://www.scribd.com. Accessed April 9, 2018.
7. American Public Health Association. 1998. Standard methods for the examination of water and wastewater. American Public Health Association, Washington, D.C.

8. Ahmed T, Urmi NJ, Munna MS, Das KK, Acharjee M, Rahman MM, et al. 2014. Assessment of microbiological proliferation and in vitro demonstration of the antimicrobial activity of the commonly available salad vegetables within Dhaka metropolis, Bangladesh. Am. J. Agri. Forestr. 2 (3): $55-60$.

9. Sharmin M, Nur IT, Acharjee M, Munshe SK, Noor R. 2014. Microbiological profiling and the demonstration of in vitro antibacterial traits of the major oral herbal medicines used in Dhaka Metropolis. SpringerPlus. 3 : 739.

10. World health Organization. 2014. Diarrhoeal disease Fact sheet №330". World Health Organization, Geneva, Switzerland.

11. Peckham EJ, Nelson EA, Greenhalgh J, Cooper K, Roberts ER, Agrawal, A. 2013. Homeopathy for treatment of irritable bowel syndrome. The Cochrane Database of Systematic Reviews. 11 (11): CD009710.

12. Ernst E. 2012. Homeopathy for eczema: a systematic review of controlled clinical trials. British J. Dermatol. 166 (6): 1170-1172.

13. Milazzo S, Russell N, Ernst E. 2006. Efficacy of homeopathic therapy in cancer treatment. European J. Cancer. 42 (3): 282-9.

14. Simonart T, Kabagabo C and De Maertelaer V. 2011. Homoeopathic remedies in dermatology: a systematic review of controlled clinical trials. The British J. Dermatol. 165 (4): 897-905.

15. Brien S, Lachance S, Prescott P, McDermott C, Lewith G. 2011 Homeopathy has clinical benefits in rheumatoid arthritis patients that are attributable to the consultation process but not the homeopathic remedy: a randomized controlled clinical trial. Rheumatol. 50 (6): 1070-82.

16. Dora MD. 2015. Homeopathic product regulation: evaluating the Food and Drug Administration's regulatory framework after a quarter-century. Testimony of the Center for Inquiry to the Food and Drug Administration. 